Jurnal Konstruksi Hukum | ISSN: 2746-5055

Vol. 2, No. 1, Januari $2021 \mathrm{Hal}$. 32-36 | Tersedia online di https://www.ejournal.warmadewa.ac.id/index.php/jukonhum

DOI: https://10.22225/jkh.2.1.2963.32-36

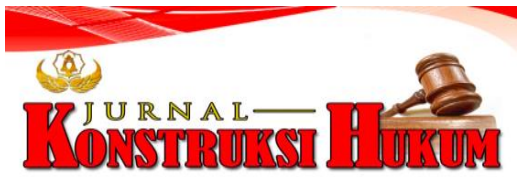

\title{
HAK CIPTA KARYA SENI LUKIS SEBAGAI JAMINAN FIDUSIA
}

\author{
Ni Kadek Emy Kencana Wati, I Nyoman Putu Budiartha, I Ketut Sukadana \\ Fakultas Hukum Universitas Warmadewa, Denpasar-Bali, Indonesia
}

\begin{abstract}
Abstrak
Pemanfaatan Hak Cipta Karya Seni Lukis dalam sistem Hukum Kekayaan Intelektual di Indonesia memberikan banyak manfaat bagi Pelukis sebagai pemilik hak cipta atau pemegang hak cipta. Seorang Pencipta atau pemegang hak cipta memiliki Hak Ekonomi atas ciptaannya yang meliputi hak untuk menggandakan, mempertunjukan, serta menyewakan ciptaannya kepada pihak ketiga. Peraturan Undang - Undang Hak Cipta Nomor 28 Tahun 2014 menyatakan bahwa Hak Cipta dapat dijadikan objek jaminan Fidusia. Penelitian ini bertujuan untuk mengetahui karakteristik Hak Cipta Karya Seni Lukis yang dapat dijadikan jaminan fidusia untuk mendapatkan kredit dalam perbankan dan menganalisis eksekusi jaminan hak cipta karya seni lukis jika debitur melakukan wanprestasi. Metode yang digunakan adalah penelitian hukum normatif dengan pendekatan perundang - undangan dan pendekatan konseptual, serta sumber bahan hukum yang digunakan adalah bahan hukum primer dan sekunder dengan teknik pengumpulan bahan hukum kepustakaan yang dianalisis dalam bentuk deskriptif analitis. Berdasarkan hasil penelitian dapat disimpulkan bahwa karakteristik Hak Cipta karya seni lukis yaitu memberikan perlindungan atas karya seni lukis serta memberikan hak ekonomi bagi pencipta atau pemegang hak cipta dan hak moral bagi pencipta. Eksekusi jaminan hak cipta dapat dilakukan dengan cara eksekutorial sesuai dengan pasal 29 Undang - Undang Fidusia.
\end{abstract}

Kata Kunci: Hak Cipta Karya Seni Lukis, Fidusia, Karakteritistik, Eksekusi

\begin{abstract}
The use of copyright for painting artworks in the Intellectual Property Law system in Indonesia provides many benefits for painters as copyright owners or copyright holders. A creator or copyright holder has Economic Rights on his work which includes the right to duplicate, display, and lease his work to third parties. Copyright Law No. 28/2014 states that copyright can be used as an object of Fiduciary security. This study aims to determine the characteristics of the copyright of painting works that can be used as fiduciary guarantees to get credit in banking and to analyze the execution of copyright guarantees of painting works if the debtor defaults The method used is normative legal research with a statutory approach and a conceptual approach, and the sources of legal materials used are primary and secondary legal materials with literature collection techniques which are analyzed in descriptive analytical form. Based on the results of the study, it can be concluded that the characteristics of copyright in painting are providing protection for works of art and providing economic rights for the creators or copyright holders and moral rights for the creators. The execution of copyright guarantees can be done by executorial method in accordance with article 29 of the Fiduciary Law.
\end{abstract}

Keywords: Copyright of Painting Art, Fiduciary, Characteristics, Execution

\section{PENDAHULUAN}

Pertumbuhan ekonomi di Indonesia sangatlah cepat. Mulai dari sektor pertanian hingga merambah dalam bidang kreatifitas. Dalam menghadapi pertumbuhan ekonomi, kemampuan yang dimiliki manusia merupakan sebuah modal untuk mengimbangi perekonomian yang ada. Di Indonesia, karya seni lukis merupakan salah satu karya yang cukup banyak dihasilkan oleh pencipta sebagai hasil dari olah pikir seseorang yang diwujudkan dalam bentuk nyata dan dapat dilihat oleh indera mata. Hak Cipta atas suatu karya seni lukis dapat menghasilkan manfaat ekonomi bagi sang pencipta karya tersebut. Hak ekonomi akan timbul setelah hasil karya lukisan tersebut didaftar ke Direktorat Jendral Hak Kekayaan Intelektual untuk diterbitkan sertifikat Hak Cipta, yang diatur dalam Undang Undang No. 25 Tahun 1999 tentang Hak Cipta.

Selain itu, ketentuan baru pada UU Hak cipta menyatakan bahwa Hak Cipta Dapat dijadikan sebagai Jaminan Fidusia. Hak Cipta merupakan benda bergerak tidak berwujud yang dapat dijadikan jaminan mendapatkan kredit di bank. Hal ini dapat disambut baik oleh para pencipta karya seni lukis sebagai bentuk mendapatkan modal untuk memperbanyak atau menghasilkan karya seni lukisan yang baru sebagailapangan pekerjaan pada kondisi perekonomian seperti ini. 
Keberadaan lembaga keuangan seperti Bank dalam hal ini sangatlah membantu perekonomian masyarakat. Bank menyediakan layanan kredit kepada debitur dalam hal permodalan atau yang lainnya. Dalam pemberian kredit, pihak bank akan meminta sebuah jaminan kebendaan guna menajamin kembalinya uang yang telah diserahkan kepada pihak debitur.

Dalam perjanjian kredit, tidak jarang salah satu pihak melakukan wanprestasi atas perjanjian yang telah dibuatnya. Hal ini dapat menimbulkan sebuah kerugian yang dialami satu pihak lainnya. Perjanjian kredit menggunakan jaminan Hak Cipta diatur dalam Undang - Undang No. 42 Tahun 1999 tentang Fidusia mulai dari pendaftaran hingga eksekusi jika debitur terbukti telah melakukan wanprestasi.

\section{METODE PENELITIAN}

Tipe penelitian yang digunakan disini adalah tipe penelitian hukum normatif. Adapun tipe pendekatan permasalahan yang digunakan untuk membahas permasalahan penelitian ini adalah pendekatan perundang-undangan dan pendekatan konseptual, dengan menggunakan induktif guna mendapatkan dan menemukan kebenaran obyektif. Sumber bahan hukum primer yang digunakan Kitab UndangUndang Hukum Perdata, Undang - Undang No. 42 Tahun 1999 tentang Fidusia, Undang - Undang No. 28 Tahun 2014 tentang Hak Cipta, Undang - Undang No. 7 tahun 1992 tentang Perbankan, Undang - Undang No. 10 tahun 1998 tentang Perubahan atas Undang - Undang No. 7 tentang perbankan, Peraturan Pemerintah No. 21 Tahun 2015 tentang Tata Cara Penerbitan Sertifikat Jaminan Fidusia dan Pembuatan Akta Jaminan Fidusia. Serta ada pula sumber bahan hukum sekunder seperti jurnal, buku, literature, dan lainnya.

\section{HASIL DAN PEMBAHASAN}

\section{Karakteristik Hak Cipta Karya Seni Lukis yang Dapat Dijadikan Jaminan Fidusia}

Hak cipta merupakan sebuah sertifikat yang menunjukan bahwa benda yang tercantum didalam sertifikat tersebut dibuktikan keberadaannya dan memberikan manfaat bagi pencipta ataupun pemegang hak cipta tersebut. Dapat dikatakan bahwa, hak cipta karya seni lukis akan memberikan kemanfaatannya kepada suatu ide yang telah dituangkan ke bentuk yang dapat dilihat ataupun dirasakan oleh indra. Menurut pasal 9 Undang-Undang No 28 Tahun 2014 tentang Hak Cipta, suatu objek ciptaan yang telah didaftarkan dan memiliki sertifikat Hak Cipta, pencipta atau pemegang Hak Cipta karya seni lukis dapat memanfaatkan hak ekonominya yang timbul sejak diterbitkan hak cipta tersebut. Hak tersebut dapat berupa perbanyakan cipta, penyewaan, pertunjukan maupun pendistribusian.

Hasil dari pemanfaatan hak cipta tersebut dinamakan Royalty. Selain itu, pencipta memiliki Hak Moral yang akan melekatsecara abadi oleh seorang pencipta. Dalam hal ini, yang dapat dikatakan Hak Moral yaitu sebuah pengakuan atas hasil karya yang diciptakan oleh seseorang yang tidak dapat diakui oleh orang lain bahwa hasil ciptaan tersebut memang benar adalah hasil dari ide yang berasal dari intelektual pencipta yang dituangkan dalam bentuk nyata.Menurut pasal 5 UU Hak Cipta, hak moral melekat dalam diri pencipta untuk tetap mencantumkan nama asli atau samarannya atas ciptaannya, hingga hak untuk mengubah, memodifikasi dan mempertahankan ciptaannya dalam hal terjadinya hal-hal yang dapat merugikan kehormatan diri dan reputasinya.

Karakteristik sebuah Hak Cipta Karya Seni Lukis dapat dilihat dari segi perlindungan yang didapat oleh pencipta karya seni tersebut. Bentuk perlindungan yang maksud berupa perlindungan dalam hal pemanfaatan hak ekonomi oleh pencipta atau pemegang hak cipta serta bentuk perlindungan hak moral yang dimiliki oleh pencipta. Hak cipta tidak melindungiide melainkan ide yang telah dituangkan dalam bentuk nyata.

Bank dalam arti luas adalah orang atau lembaga yang dalam pekerjaannya secara teratur menyediakanuang untuk pihak ketiga (Andy, 2005:10). Dalam pemberian kredit, bank akan membuat sebuah perjanjian dengan pihak debitur selaku peminjam uang di bank yakni perjanjian kredit. Perjanjian menggunakan jaminan fidusia merupakan salah satu perjanjian kepercayaan dari pihak bank selaku kreditor, karena dalam perjanjian pihak bank tidak menguasai penuh benda jaminan yang akan dijaminkan oleh debitur.Perjanjian kredit merupakan perjanjian pokok yang akan melahirkan perjanjian kebendaan. Perjanjian kebendaan bersifat assesoir atau ikutan yang ada karena adanya perjanjian pokok antara debitur dan kreditor. 
Perjanjian merupakan peraturan yang dibuat dan dilaksanakan oleh pihak yang menyetujui isi dari perjanjian tersebut. Sebuah perjanjian akan melahirkan sebuah perikatan yang akan mengikat pihak - pihak yang terkait didalamnya. Para pihak akan melaksanakan prestasi yang tercantum di dalam perjanjian yang telah disetujui. Prestasi menurut undang - undang berupa:

1. Menyerahkan suatu barang

2. Melakukan suatu perbuatan

3. Tidak melakukan suatu perbuatan (Subekti, 2003:123).

Perjanjian pokok dibuat dihadapan Notaris dengan akta otentik sedangkan perjanjian kebendaan dibuat di Kantor pendaftaran Fidusia sebagai bukti bahwa benda tersebut sedang dijaminkan. Proses pembebanan jaminan ini dilakukan dengan tujuan untuk dapat dilaksanakan title eksekusi yang mengenai benda jaminan fidusia. Dalam proses ini pembebanan dilakukan pada sertifikat Hak Cipta Karya Seni Lukis sebagai objek yang dijadikan jaminan oleh debiturdalam perjanjian kredit.Namun berbeda halnya apabila terjadi pembebanan pada Hak Cipta karena Hak Cipta merupakan suatu benda bergerak tidak berwujud yang dimana eksistensinya tidak jelas terlihat maka secara kasar bukan benda atau barangnya yang menjadi jaminan melainkan hak yang melekat pada jaminan tersebut (Usman, 2011:282).

Menurut Pasal 11 ayat (1) UU Fidusia yang menyatakan bahwa benda yang dibebani dengan Jaminan Fidusia wajib didaftarkan. Pendaftaran jaminan Fidusia yang akan dibebankan Jaminan Fidusia dilakukan di Kementerian Wilayah Hukum dan HAM. Pasal 6 UU Fidusia menyatakan bahwa dalampembebanan jaminan fidusia, pada akta jaminan harus memuat mengenai spesifikasi benda jaminan mulai dari identitas pihak pemberi jaminan, uaraian mengenai kondisi jaminan hingga nilai jaminan yang akan dijadikan jaminan kredit.Mengenai nilai jaminan Hak Cipta, dapat ditinjau dari perjanjian yang dibuat oleh pihak debitur dengan pihak ketiga untuk memanfaatkan hak ekonomi yang dimiliki.

\section{Eksekusi Jaminan Hak Cipta Karya Seni Lukis Jika Debitur Wanprestasi}

Eksekusi merupakan tindakan yang dilakukan oleh kreditor jika terbukti debitur telah melakukan wanprestasi atas perjanjian yang telah disetujui. Dalam proses eksekusi benda jaminan yang dijadikan jaminan oleh debitur akan diambil alih oleh kreditor untuk pelunasan hutang yang telah ada. Pengambil alihan ini, dimaksudkan untuk menjual benda jaminan untuk pelunasan hutang debitur yang tersisa. Eksekusi atau pelaksanaan putusan hakim pada hakekaktnya tidak lain adalah realisasi dari kewajiban pihak yang bersangkutan untuk memenuhi prestasi yang tercantum dalam putusantersebut (Mertokusumo, 2010:209).

Dasar dilakukannya eksekusi yaitu seritifikat Jaminan Hak Cipta Karya Seni Lukis yang telah dibebankan jaminan fidusia. Pelaksanaan eksekusi dengan jaminan Hak Cipta karya Seni Lukis dilakukan sesuai dengan ketentuan Undang - Undang No 42 Tahun 1999 tentang Fidusia. Dalam eksekusi jaminan Hak Cipta Karya Seni Lukis, dapat dilakukan dengan eksekutorial oleh pihak kreditor. Hal ini didukung dengan tercantumnya irah - irah "Demi Keadilan Berdasarkan Ketuhanan Yang Maha Esa" sesuai dengan pasal 15 UU Fidusia yang menyatakan bahwa irah - irah tersebut memiliki kekuatan eksekutorial yang sama dengan putusan pengadilan yang memiliki kekuatan hukum tetap. Dalam hal eksekusi jaminan, kreditor dapat melakukan sendiri eksekusi jika terbukti debitur telah melakukan wanprestasi.

Pelaksanaan eksekusi oleh peneriman fidusia dengan tittle eksekutorial, penerima dapat mengacu pada asas-asas yang melekat pada jaminan Hak Cipta Karya Seni Lukis. Menurut Sutan Remy Sjahdeini, asas yang dapat digunakan dalam ekesekusi jaminan Hak Cipta Karya Seni Lukis yaitu:

1. Memberikan Kedudukan Yang Didahulukan Bagi Pemegang Hak Jaminan terhadap Kreditur Lainnya (Asas Prioritas).

Pada Pasal 27 UU Fidusia asas mendahului merupakan asas dimana jika debitur melakukan wanprestasi terhadap perjanjian kredit yang disetujuinya, dan pada saat proses eksekusi ditemukan bahwa benda jaminan ternyata telah dijaminankan kepada lebih dari satu kreditor maka, kreditor yang memiliki sertifikat jaminan Hak Cipta Seni Lukis yang telah dibebankan oleh Kantor pendaftaran Fidusia berhak mengeksekusi terlebih dahulu benda jaminan tersebut.

2. Bersifat Asesoir terhadap perjanjian pokok yang dijamin dengan jaminan 
Fidusia Perjanjian kebendaan merupakan perjanjian ikutan yang lahir dari adanya perjanjian pokok yaitu perjanjian kredit antara kreditor dan debitur mengenai utang - piutang.

3. Memberikan Hak Separatis bagi kreditor pemegang hak jaminan

Penjelasan pasal 27 UU Fidusia yang meyatakan bahwa hak didahulukan yang dimiliki oleh peneriman fidusia tidak akan hilang karena pihak debitur ditanyakan pailit dan atau likuidasi pemberi fidusia. Jaminan Fidusia merupakan jaminan untuk pelunasan hutang debitur, maka dari itu jaminan fidusia tidak termasuk dalam harta pailit yang dimiliki oleh debitur. Hak Separatis penjaminan debitur melakukan pelunasan hutang kepada debitur dengan cara mengeksekusi benda jaminan yang dikuasainya sebagai jamianan atas pelunasan utangnya.

4. Merupakan Hak Kebendaan (Asas Deroit de Suite)

Asas Deroit de Suite merupakan asas kebendaan yang dimiliki oleh benda jaminan fidusia. Jika dalam proses eksekusi yang dilakukan oleh pihak kreditor menemukan bahwa benda jaminan tidak dikuasi oleh debitur maka asas ini dapat dilaksanakan. Asasderoit de suite merupakan asas yang mengikuti benda jaminan kemana pun benda jaminan berada dan tangan siapapun benda jaminan dikuasai. Kreditur, sebagai pemegang jaminan fidusia dapat mengekseskusi benda jaminan berdasarkan asas ini jika benda jaminan tidak dikuasi oleh pihak debitor. Pasal $20 \mathrm{UU}$ Fidusia menegaskan bahwa jaminan fidusia akan mengikuti benda yang menjadi objek jaminan pada tangan siapapun benda tersebut berada.

5. Kreditur pemegang hak jaminan mempunyai kewenangan penuh untuk melakukan eksekusi atas hak jaminan

Kekuatan eksekutorial yang dimiliki oleh kreditor, dapat megeksekusi jaminan tidak melalui keputusan pengadilan. Hal ini telah dicantumkan pada pasal 15 UU Fidusia jika debitur cidera janji maka penerima fidusia yaitu pihak kreditor mempunyai hak untuk mengeksekusi benda jaminan dengan cara dijual melalui pelelangan umum atau pun penjualan dibawah tanganatas kekuasaannya sendiri.

6. Berlaku bagi Pihak Ketiga, dimana berlaku pula Asas Publisitas

Benda Jaminan Fidusia harus didaftarkan untuk menjalankan asas publisitas. Asas Publisitas merupakan sebuah "pengumuman" yang dibuat untuk masyarakat mengenai status kepemilikan benda jaminan Hak Cipta Karya Seni Lukis yang baru. Ketentuan mengenai asas publisitas diatur pada pasal 11 ayat (1) UU Fidusia yang mengatur mengenai benda jaminan fidusia harus didaftarakan. Pemberitahuan kepada pihak ketiga atau masyarakat mengenai Asas ini menyangkut mengenai pemanfaat hak ekonomi yang dimiliki oleh hak cipta tersebut.

Dalam pemberian kredit menggunakan agunan, pihak bank akan mempertimbangkan nilai ekonomi dari benda tersebut, karena bank merupakan perusahaan yang mencari profit maka dari itu benda jaminan yang akan dijaminkan harus memiliki market place yang luas sehingga pada proses eksekusi jaminan akan mudah dalam penjualan benda jaminan untuk menutup hutang debitur (wawancara dengan Putu Eviyanti tanggal 24 Pebruari 2020).

Eksekusi jaminan fidusia dapat dilakukan sendiri oleh kreditor selaku penerima jaminan fidusia yang didukung dengan adanya sertifikat jaminan Hak Cipta Karya Seni Lukis yang memiliki kekuatan eksekutorial. Jaminan debitur yang dapat dieksekusi merupakan jaminan dari debitur yang dalam proses pelunasannya mengalami macet. Sebelum melakukan tindakan sita jaminan yang dilakukan oleh pegawai khusus yang menangani bidang eksekusi jaminan, pihak debitur telah menerima surat peringatan yang dikirimkan oleh pihak bank. Namun jika hingga surat peringatan ke - 3 tidak ada tanda niat baik dari debitur, maka pihak bank akan mengambil tindakan eksekusi jaminan sesuai dengan perjanjian kredit yang dibuat dihadapan Notaris (wawancara dengan Adi Nugraha, tanggal 21 Pebruari 2020).

Eksekusi jaminan tidak dapat dilakukan jika terbukti bahwa benda jaminan yang dibebankan dengan jaminan fidusia tidak ada secara permanen atau musnah karena bencana alam atau secara temporer objek jaminan fidusia tidak diketahui keberadaannya karena telah dialihkan kepada pihak lain oleh debitur secara melawan hukum. Namun, apabila dikemudian hari pihak kreditor mengetahui keberadaan objek jaminan Hak Cipta Karya Seni Lukis tersebut maka proses eksekusi dapat dilakukan kembali untuk melunasi hutang debitur.

Pelaksanaan eksekusi jaminan fidusia menggunakan tittle eksekutorial sesuai dengan ketentuan pasal 29 UU Fidusia serta melalui cara pelelangan umum dan penjualan dibawah tangan. The right to reposses diberikan oleh undang - undang kepada penerima fidusia (kreditor) dalam kedudukan dan 
kapasitasnya sebagai legal owner dan economiz owner atas objek jaminan fidusia, atau secara bersama sama dengan pihak berwenang melakukan eksekusi atas objek jaminan fidusia (Harahap, 2009:215).

Menurut Djoko Hadi Santoso, ekseksi jamianan Hak Cipta dapat dilakukan dengan dua cara yaitu pelelangan umum dan penjualan dibawah tangan. Ketentuannya adalah untuk debitor dalam melaksanakan semua perjanjian dalam kreditor, tentu dan harus di Bank yang sama artinya bahwa Bank sebagai kreditor untuk penyaluran modal dan Bank juga sebagai rekening penerima royalty dari hasil penggunaan hak ekonomi pencipta.

Penjualan benda jaminan melalui pelelangan umum dapat dilaksanakanmenjual menjual hak ekonomi yang dimiliki oleh pencipta atau pemegang hak cipta berikut dengan segala royalty yang merupakan hak tagih dimasa mendatang hasil dari pemanfaatan hak ekonomi dari Hak Cipta dapat dijual oleh pihak bank sebagai kreditor. Ketentuan ini juga tercantum pada pasal 29 ayat (1) UU Fidusia.

Pihak kreditor yang melaksanakan eksekusi terhadap jaminan Hak Cipta Karya Seni Lukis, apabila hasil dari penjualan tersebut melebihi utang dari debitur maka sisa hasil pelunasan utang tersebut harus dikembalikan ke pihak debitur. Namun, apabila hasil penjualan benda jaminan tidak mencukupi untuk melunasi hutang debitur maka pihak kreditor dapat mengeksekusi benda jaminan yang dimiliki debitur sekarang atau yang akan ada sesuai dengan pasal 1131 Kitab Undang - Undang Hukum Perdata.

\section{SIMPULAN DAN SARAN}

\section{Simpulan}

Karakteristik Hak Cipta Karya seni Lukis yaitu memberikan perlindungan atas ciptaan karya seni lukis serta memberikan hak ekonomi dan hak moral bagi pencipta. Nilai ekonomis Hak Cipta Karya seni Lukis dapat ditinjau dari pemanfaatan hak ekonomi pencipta yang meliputi nilai kontrak antara pencipta dan perusahaan atau perorangan dalam pemanfaatan hak ekonomi dari pencipta yang dapat meliputi hasil penjualan, pertunjukan, ataupun penggandaan objek Hak Cipta Karya Seni Lukis. Proses pembebanan Hak Cipta Karya Seni Lukis sebagai jaminan Fidusia dilakukan dihadapan Notaris dengan Akta Otentik. Kemudian, eksekusi jaminan Hak Cipta Karya Seni Lukis jika debitur cidera janji dilakukan dengan cara eksekutorial. Tindakan eksekusi benda jaminan Hak Cipta Karya Seni Lukis yang dilakukan kreditor dapat dilaksanakan dengan cara melakukan penjualan benda jaminan secara lelang umum dan penjualan benda jaminan dibawah tangan, dengan memindahkan nilai Hak Cipta dan memindahkan hak ekonomi dari Hak Cipta kepada pihak ketiga.

\section{Saran}

Dalam menciptakan sebuah karya seni lukis, pelukis hendaknya mendaftarkan hasil karya seni lukis ke Dijen HKI untuk memperoleh Hak Cipta atas karya seni lukis tersebut. Hal ini dapat memberikan manfaat ekonomi lebih untuk menunjang perekonomian bagi Pelukis serta memberikan kekayaan yang berbentuk immaterial. Berdasarkan wawancara mengenai jaminan Hak Cipta Karya Seni Lukis, Peran Pemerintah dalam hal ini dapat berupa penyediaan pihak - pihak yang mengetahui akan nilai jual Lukisan serta mengetahui mengenai Hak Cipta Seni Lukis yang dapat dijadikan jaminan Fidusia. Selain itu, Pemerintah juga sebaiknya menyediakan market place yang tepat untuk mempermudah proses eksekusi jika debitur wanprestasi.

\section{DAFTAR PUSTAKA}

Andy. (2005). Kredit Perbankan Indonesia. Yogyakarta: PT. Citra Aditya Bakti. Harahap, M. Y. (2009). Ruang Lingkup Permasalahan Eksekusi Bidang Perdata. Jakarta: Sinar Grafika. Mertokusumo, S. (2010). Hukum Acara Perdata Indonesia (Edisi revisi). Yogyakarta: Cahaya Atma Pustaka. Subekti, R. (2003). Pokok-Pokok Hukum Perdata. Jakarta: Intermasa. Usman, R. (2011). Hukum Kebendaan. Jakarta: Sinar Gafika. Undang - Undang Nomor 42 Tahun 1999 tentang Fidusia Undang Undang Nomor 28 Tahun 2014 Tentang Hak Cipta 